\title{
WHOLE-BODY METABOLISM DURING AND AFTER ABDOMINAL SURGERY*
}

\author{
Otro H. Horrelt, M.D., Sait Tarhan, M.D., and Emerson A. Moffitt, M.D. $\dagger$
}

NUMErOUS PAPERS have been written on the effect of general anaesthesia and surgical procedures on one or more of the various aspects of metabolism, but none correlates many measurable variables in the same patients. Better understanding of the changes occurring in the body during and after operation should improve the safety of the operation. Improper oxygenation, acid-base imbalance, and abnormal potassium, calcium, and sodium concentrations have potent ill effects on the heart and body.

Metabolism of non-esterified fatty acids (NEFA) is the major source of energy in the fasting state, and the production of ketone bodies reflects the carbohydrate deprivation of fasting. Lactate and pyruvate are also sources of energy as well as being indicators of anaerobic metabolism. Studies of myocardial and whole-body metabolism in patients undergoing open-heart surgery have delineated patterns of changes and indicated improvements in treatment. ${ }^{1-3}$

The purpose of this study was to investigate changes in metabolites and electrolytes, on a whole-body basis, in a group of patients undergoing abdominal surgery, and to document their responses to anaesthesia and this type of surgery. Another aim of the study was to help to determine, in the previously studied patients having open-heart surgery, the proportion of the changes due to the cardiac lesion and the whole-body perfusion.

\section{Material AND Methods}

In 11 adult patients (ages 36 to 79 years; mean 55 years), arterial and right atrial blood samples were drawn simultaneously during abdominal surgery and for the next three days. The samples taken before induction of anaesthesia were used as controls. Six patients underwent insertion of aorto-iliac grafts for occlusive vascular disease, and five had other types of abdominal surgery. The mean weight of the 11 patients was 147 pounds (range, 127 to 194 pounds). The physical status of the patients (American Society of Anesthesiology classification) was: class I, two; class 2, seven; and class 3 , two. All patients had satisfactory postoperative courses and left the hospital an average of 13 days later.

For anaesthesia, nitrous oxide ( $3 \mathrm{~L})$, oxygen $(2 \mathrm{~L})$, and halothane $(0.25$ to 0.75 per cent) were administered with a semiclosed circle absorber system and manually controlled ventilation. Thiopental sodium ( 125 to $375 \mathrm{mg}$ ) and succinyl-

'Read at the meeting of the Canadian Anaesthetists' Society, Toronto, June 15 to $19,1969$. This investigation was supported in part by research grant GM-14919 from the US National Institutes of Health, Public Health Service.

†Mayo Clinic and Mayo Foundation: Section of Anesthesiology and Mayo Graduate School of Medicine (University of Minnesota), Rochester. 


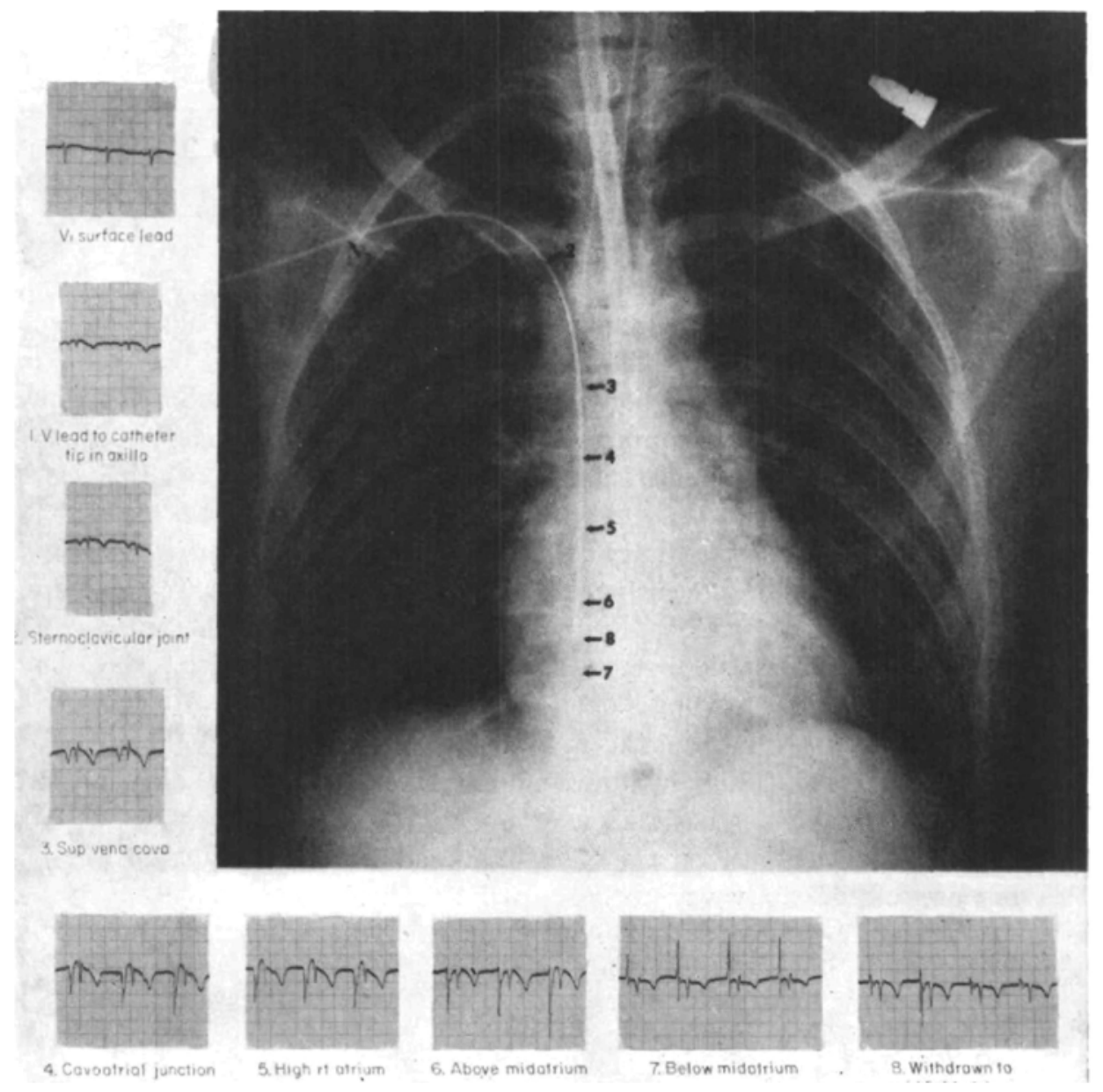

FIGURE 1. Electrocardiographic features used to guide placement of right atrial catheter.

choline chloride $(60 \mathrm{mg}$ ) were given for induction and endotracheal intubation. Intermittent doses of succinylcholine chloride were used when necessary for muscle relaxation. Duration of operation was 55 minutes to 2 hours and 30 minutes.

Simultaneous blood samples were taken in heparinized syringes from the right atrium and a peripheral artery. A catheter was inserted from the brachial vein to the right atrium by electrocardiographic guidance ${ }^{4}$ (Fig. 1). The position was further verified on a postoperative roentgenogram. This method of placement was uniformly successful. Right atrial samples were accepted for mixed venous blood because of the danger of arrhythmia associated with attempts to float a catheter into the pulmonary artery. ${ }^{5}$ Samples were drawn before anaesthesia (breathing air), at the middle of the operation, and at the end of anaesthesia, the latter when the patients were spontaneously breathing oxygen via a tightly fitting face mask. Further samples were taken two hours postoperatively and at 1 PM on each 
of the following three days while the patient was breathing oxygen via a face tent (Puritan Co.) for at least ten minutes.

Samples for blood gas analysis were transported in ice and analysed for oxygen and carbon dioxide tensions and $\mathrm{pH}$ by electrodes maintained at $37^{\circ} \mathrm{C}$ (Instrumentation Laboratory Inc.). Haematocrit values were determined in an International clinical centrifuge, and buffer base was read from the Singer-Hastings nomogram. ${ }^{6}$

Serum concentrations of NEFA, ${ }^{7}$ total ketone bodies, ${ }^{8}$ and calcium ${ }^{9}$ were determined by reported methods. Serum sodium and potassium were measured by flame photometry. Enzymatic methods were used to measure blood lactate and pyruvate. ${ }^{10}$ Plasma osmolality was determined by freezing-point depression (Fiske osmometer). Whole blood glucose was measured in an AutoAnalyzer (Technicon Corporation). Serum immunoreactive insulin concentration was measured by double-antibody radioimmunoassay. ${ }^{11}$

The fluid administered intravenously, during operation and for two hours postoperatively, was 5 per cent dextrose in water, approximately $50 \mathrm{ml}$ being given as a vehicle for intravenous drugs. Blood was given when necessary, the average amount being $750 \mathrm{ml}$. Postoperatively, intravenous fluids were given at the average rate of $1,500 \mathrm{ml} /$ day. The usual regimen per 24 hours was $1,000 \mathrm{ml}$ of 5 per cent dextrose in water and $500 \mathrm{ml}$ of 5 per cent dextrose in saline.

Statistical analyses were done by Student's $t$-test with $p=0.05$ accepted as the level of significance for comparison of paired data for each parameter: (a) arterial and right atrial levels at each sampling time, and $(b)$ each subsequent arterial concentration compared to the preinduction control level.

\section{Results}

The mean values with standard error of the mean for arterial and right atrial blood for all parameters are given in Table I. Table II shows all the significant differences between arterial and right atrial concentrations of variables. Table III is a summary of significant differences between arterial control concentrations and subsequent arterial samples. No significant differences in any variable were found between the group undergoing aorto-iliac grafting and those having other abdominal operations. All differences to be mentioned were statistically significant.

Acid-base balance. Buffer base did not change across the body, nor did arterial levels change with time (Fig. 2). $\mathrm{PCO}_{2}$ increased across the body and $\mathrm{pH}$ decreased significantly across the body at most sample times. Respiratory alkalosis was present throughout operation and on days 3 and 4 .

Electrolytes. No arteriovenous differences were found in sodium, potassium, calcium, or osmolality (Figs. 3 and 4). Osmolality was near the lower limit of the normal range at almost all times. Arterial levels of potassium midway through the operation were lower than before induction of anaesthesia. Calcium showed no changes in any respect. Arterial sodium levels were below the preinduction value at all sampling times except at the end of the operation and two hours later. This mild hyponatraemia was still present on day 4.

Metabolites. No arterionvenous differences were seen in any of the metabolites. 


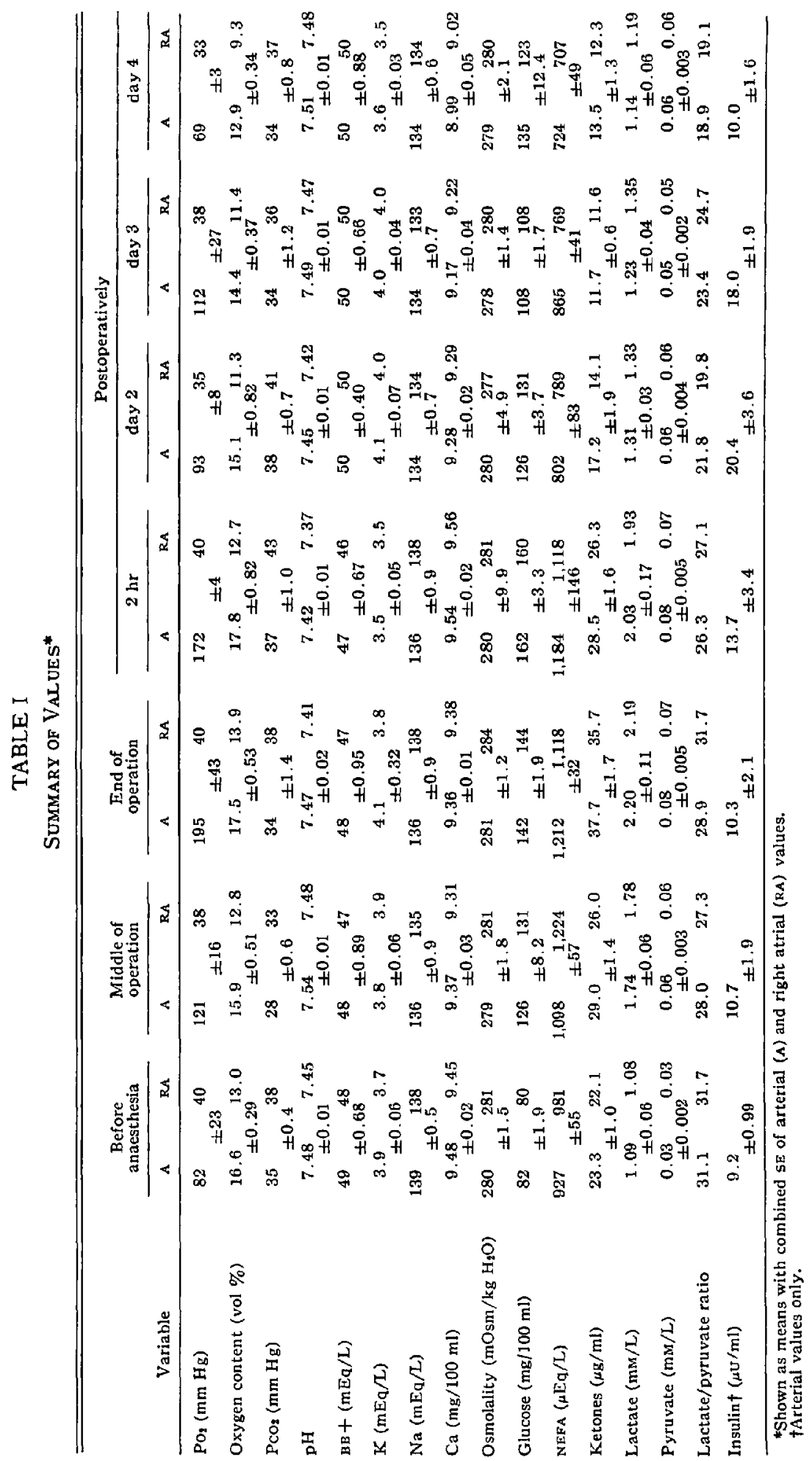


TABLE II

Summary of Significant Differences* between Arterial AND Right Atrial BLOOD

\begin{tabular}{lll} 
Variable & $\begin{array}{l}\text { Right atrial } \\
\text { significantly } \\
\text { higher than } \\
\text { arterial at: }\end{array}$ & $\begin{array}{l}\text { Right atrial } \\
\text { significantly } \\
\text { lower than } \\
\text { arterial at: }\end{array}$ \\
\hline $\mathrm{pH}$ & no time & $\begin{array}{l}\text { all times except } \\
\text { end of operation } \\
\text { and day } 3\end{array}$ \\
$\mathrm{PCO}_{2}$ & $\begin{array}{l}\text { all times except } \\
\text { day } 3\end{array}$ & no time \\
$\mathrm{PO}_{2}$ & no time & all times \\
$\mathrm{O}_{2}$ content & no time & all times \\
$\mathrm{O}_{2}$ saturation & no time & all times \\
\hline${ }^{*} p<0.05$. & &
\end{tabular}

TABLE III

Summary of Significant Differences* between Arterial Control and SubSEquent ARTERIal Samples

\begin{tabular}{|c|c|c|}
\hline Variable & $\begin{array}{l}\text { Significantly } \\
\text { higher than } \\
\text { control at: }\end{array}$ & $\begin{array}{l}\text { Significantly } \\
\text { lower than } \\
\text { control at: }\end{array}$ \\
\hline $\mathrm{pH}$ & day 4 & no time \\
\hline $\mathrm{PCO}_{2}$ & no time & middle of operation \\
\hline $\mathrm{BB}+$ & no time & no time \\
\hline Haematocrit & $\begin{array}{l}\text { end of operation and } \\
2 \mathrm{hr} \text { postop. }\end{array}$ & days 3 and 4 \\
\hline $\mathrm{PO}_{2}$ & no time & no time \\
\hline $\begin{array}{l}\mathrm{O}_{2} \text { content } \\
\mathrm{O}_{2} \text { saturation }\end{array}$ & 2 hr postop. & $\begin{array}{l}\text { days } 3 \text { and } 4 \\
\text { no time }\end{array}$ \\
\hline $\mathrm{Na}$ & no time & $\begin{array}{l}\text { all times except } \\
\text { end of operation }\end{array}$ \\
\hline & & and $2 \mathrm{hr}$ postop. \\
\hline $\mathrm{K}$ & no time & middle of operation \\
\hline $\mathrm{Ca}$ & no time & no time \\
\hline Osmolality & no time & no time \\
\hline Lactate & $\begin{array}{l}\text { during operation and } \\
2 \mathrm{hr} \text { postop. }\end{array}$ & no time \\
\hline Pyruvate & all times & no time \\
\hline NEFA & $\begin{array}{l}\text { during operation and } \\
2 \mathrm{hr} \text { postop. }\end{array}$ & no time \\
\hline Glucose & all times & no time \\
\hline Total ketone bodies & no time & no time \\
\hline Insulin & days 2 and 3 & no time \\
\hline
\end{tabular}

Total ketone bodies (Fig. 5) were above normal range before induction of anaesthesia and remained so throughout the study. NEFA was slightly increased before induction and was higher than control during operation and two hours postoperatively. 


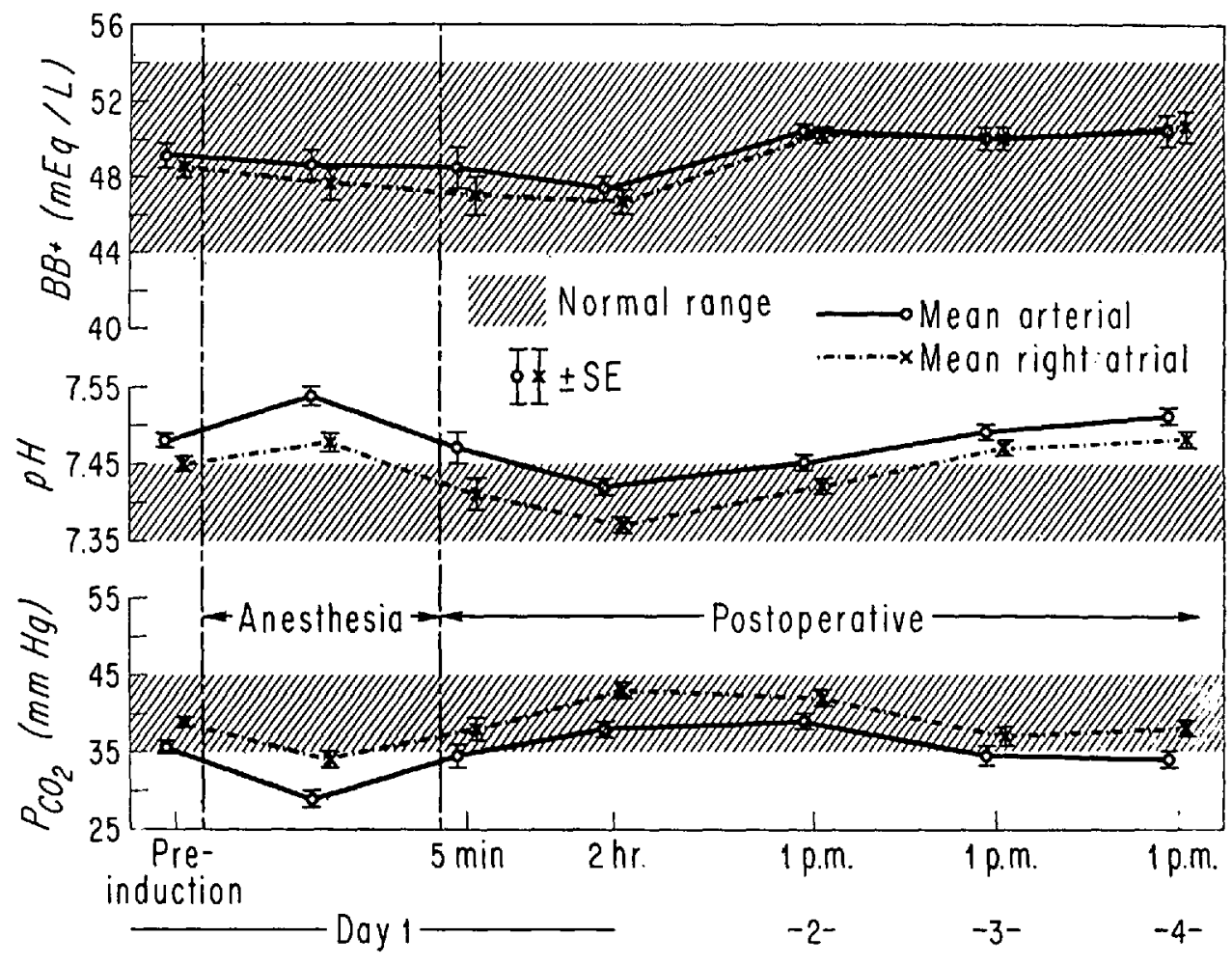

Ficure 2. Acid-base balance. In all figures, day $I$ is the day of operation and postoperative days are designated days 2,3 , and 4 . Buffer base did not change throughout the study. Respiratory alkalosis was present during anaesthesia and on days 3 and 4 .

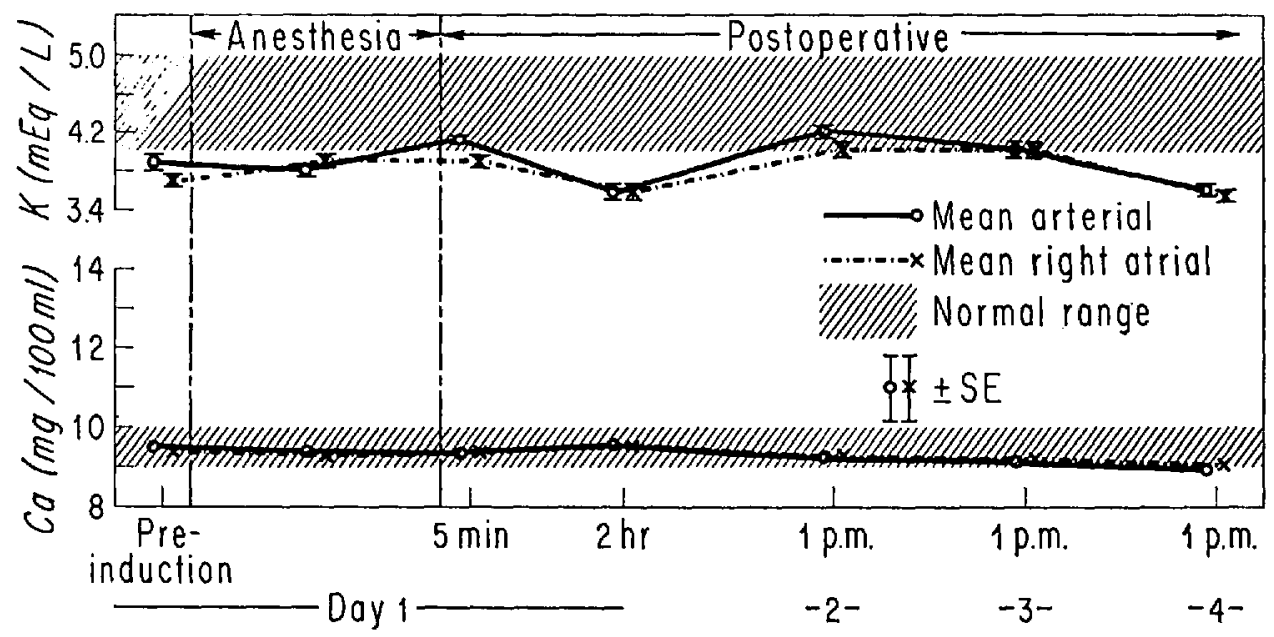

Figure 3. Serum potassium and calcium concentrations. Potassium remained in low normal range or below throughout. Calcium showed no changes. 
HORRELT et al.: WHOLE-BODY METABOLISM DURING ABDOMINAL SURGERY

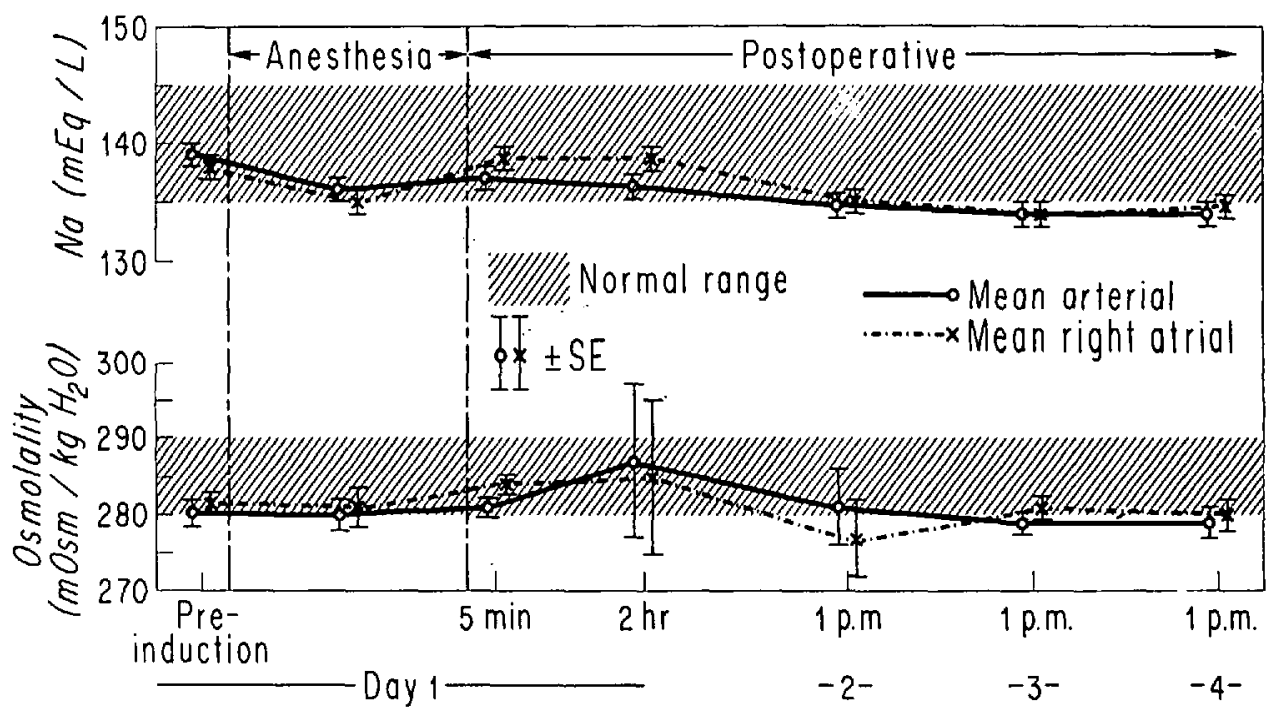

Figure 4. Serum sodium concentration and osmolality. Gradual decrease in sodium was seen, with no arteriovenous differences. Osmolality, indicative of the water content of the blood, was usually close to the lower limit of the normal range, signifying high-normal proportions of serum water.

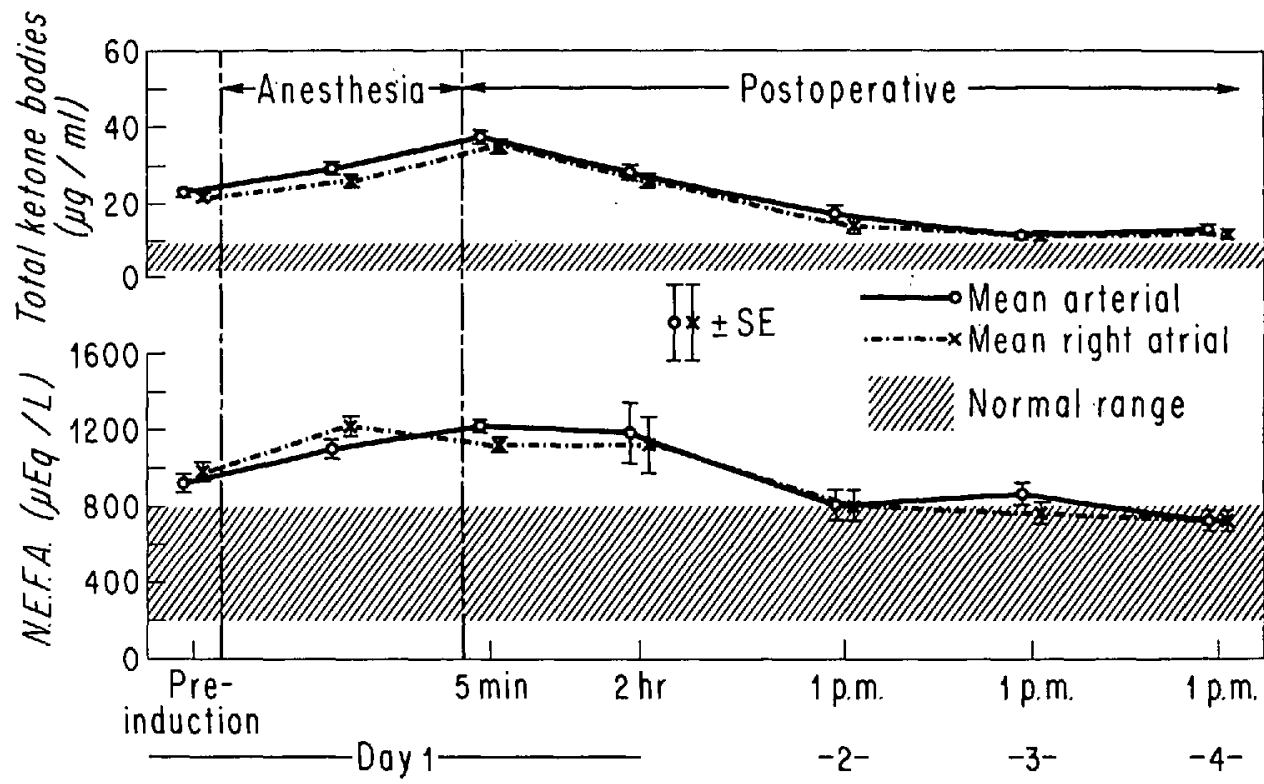

Frgune 5. Total ketone bodies and non-esterified fatty acids. Ketone bodies increased during anaesthesia and were above normal range at all times. Arterial NEFA concentration remained above normal range on the day of operation. 


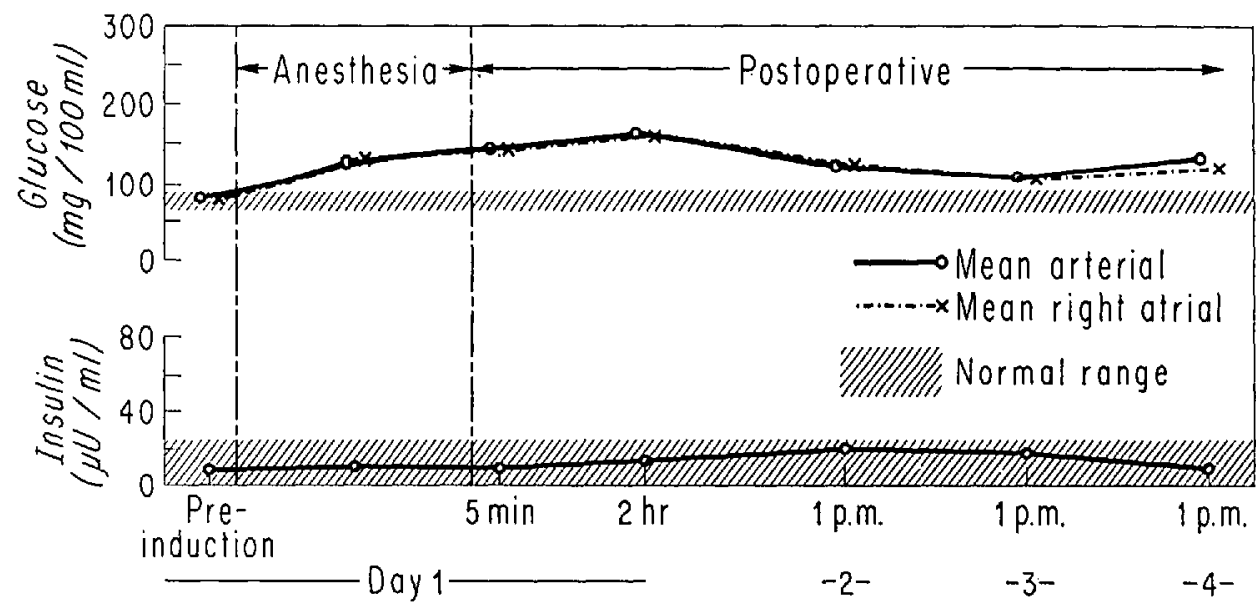

Frgure 6. Glucose and insulin concentrations. Glucose remained above normal range from induction through the whole study. Arteriovenous differences were not detected. Insulin remained within normal range but increased above control on days 2 and 3 .

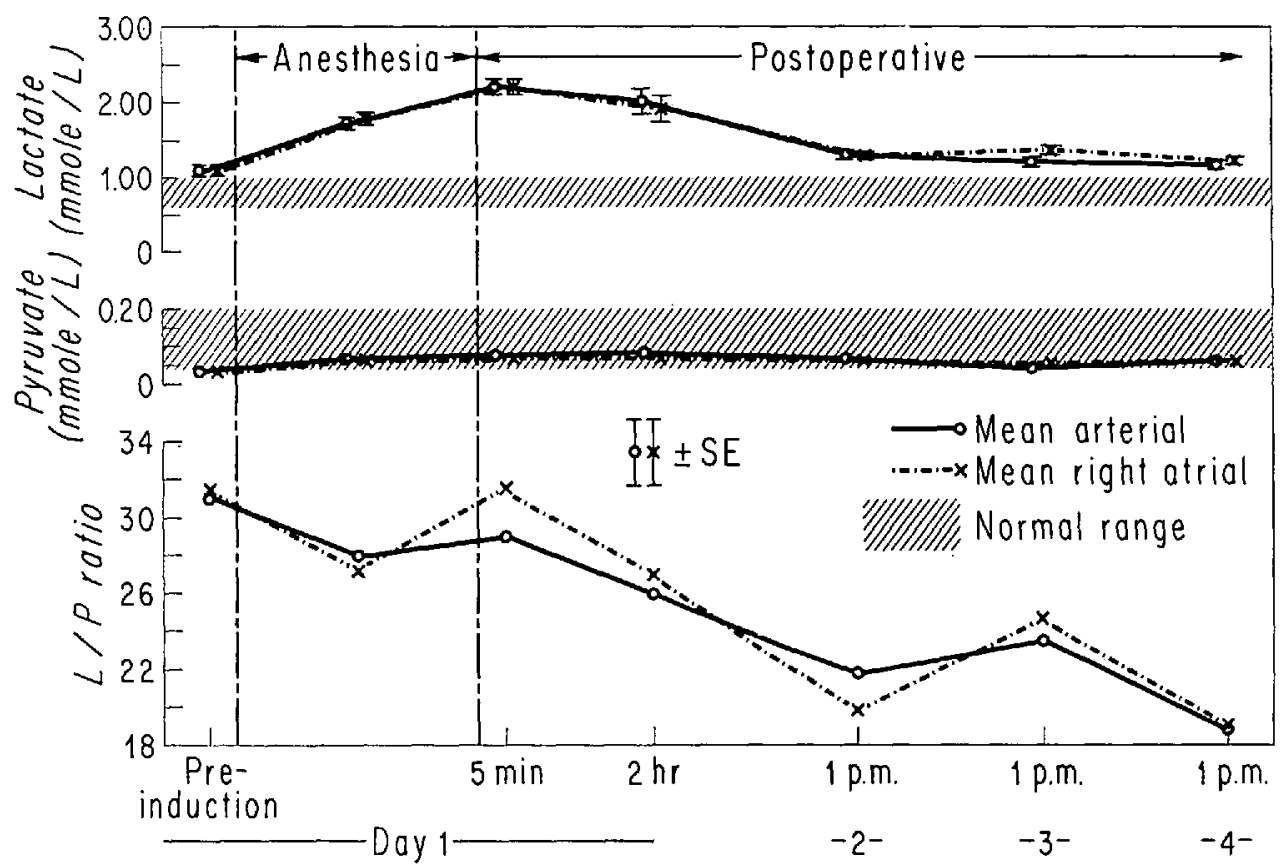

Figure 7. Lactate, pyruvate, and $\mathrm{L} / \mathrm{P}$ ratio. Lactate increased to a peak at the end of operation but was not different from control postoperatively. Venous lactate was not different from arterial levels. Pyruvate was higher than control throughout the study.

The intravenously administered glucose contributed to the higher-than-preinduction levels of glucose in the arterial blood through the study period (Fig. 6).

The mean concentration of immunoreactive insulin remained within the normal 
range ( 0 to $25 \mu \mathrm{v} / \mathrm{ml}$ ) throughout (Fig. 6 ). It increased above preinduction level on days 2 and 3.

Lactate (Fig. 7) was slightly increased before induction and remained higher than control through the operation and two hours postoperatively. Pyruvate and $\mathbf{L} / \mathbf{P}$ ratio were above control throughout the study.

Large arteriovenous oxygenation differences were present at all times (Fig. 8). Mean venous oxygen tension remained at 38 to $40 \mathrm{~mm} \mathrm{Hg}$ throughout the day of operation but decreased to $33 \mathrm{~mm} \mathrm{Hg}$ on day 4. Arterial oxygen tension averaged 93,112 , and $69 \mathrm{~mm} \mathrm{Hg}$ on the three postoperative days while the patients were breathing approximately 40 per cent oxygen. Oxygen content of the arterial blood was higher than control two hours after operation, because of a higher haemoglobin concentration; on days 3 and 4 it was lower than control, with a decreased haemoglobin concentration.

\section{Discussion}

It is essential to have continuous satisfactory arterial oxygen tension during anaesthesia, and this can be accomplished by keeping the $\mathrm{F}_{\mathrm{O}_{2}}$ above 0.4 in the presence of a satisfactory cardiac output. For many years it has been suggested that a $\mathrm{Pa}_{\mathrm{O}_{2}}$ of approximately $100 \mathrm{~mm} \mathrm{Hg}$ was a minimal requirement for safe anaesthesia. ${ }^{12}$ The factors that may contribute to a low $\mathrm{Pa}_{\mathrm{O}_{2}}$ when the inspired oxygen concentration is kept adequate are hypoventilation, reduction in diffusing capacity, ventilation-perfusion abnormalities, pulmonary shunting, and decrease in

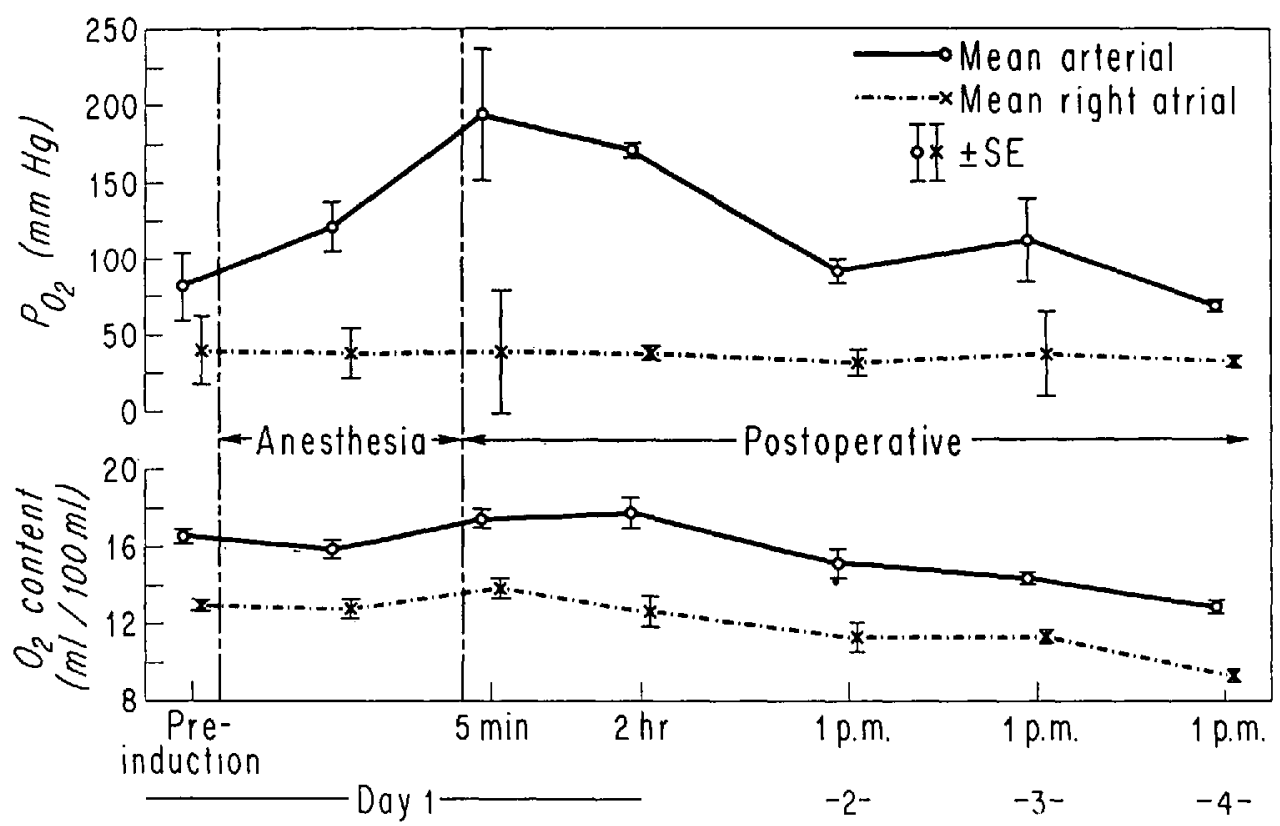

Figure 8. Oxygen tension and content. Mean arterial tension was satisfactory when $\mathrm{Fr}_{\mathrm{O}_{2}}$ was increased, except on day 4. Right atrial tension remained stable. Postoperatively, oxygen content decreased as blood haemoglobin level decreased. 
cardiac output. ${ }^{13}$ The haemodynamic state remained stable in our patients, as judged by clinical criteria, and the carbon dioxide levels were subnormal, showing the absence of hypoventilation. Changes of diffusing capacity were not known. Thus, shunting and uneven distribution of ventilation plus perfusion abnormalities stand out as the major factors contributing to the decreased $\mathrm{Pa}_{\mathrm{O}_{2}}$ values.

In our patients, oxygenation was satisfactory throughout the operation, although a mean $\mathrm{Pa}_{\mathrm{O}_{2}}$ of $121 \mathrm{~mm} \mathrm{Hg}$ with an $\mathrm{F}_{\mathrm{O}_{2}}$ of 0.4 indicates considerable shunting. Stephen and Talton found a mean $\mathrm{Pa}_{\mathrm{O}_{2}}$ of $80 \mathrm{~mm} \mathrm{Hg}$ (patients breathing air) two hours after anaesthesia. ${ }^{14}$ Hamilton and co-authors found arterial oxygen desaturation for two days postoperatively. ${ }^{15}$ The postoperative $\mathrm{F}_{\mathrm{I}_{2}}$ in our series is not definitely known because a loose face tent was used, but the values would have been even lower had the patients been breathing air. The fact that shunting of significant magnitude continues in the postoperative period has been shown by Tarhan and co-workers. ${ }^{16}$ Clowes and associates ${ }^{17}$ observed that oxygen desaturation was greatest 24 hours after operation. Our lowest mean arterial tension occurred on day 4. Nunn and Payne ${ }^{18}$ also have shown that hypoxemia commonly occurs after general anaesthesia, attributable to miliary atelectasis. The likelihood of its presence in every patient should be remembered, and efforts to reduce atelectasis should be made in addition to giving oxygen postoperatively.

The respiratory alkalosis occurring during operation was intentionally produced. Buffer base did not change significantly as blood traversed body tissues, nor did arterial levels change with time. Postoperatively, a mild respiratory alkalosis recurred, greatest on day 4 when $\mathrm{Pa}_{\mathrm{O}_{2}}$ was lowest. Tachypnoea and shallow breathing from incisional pain may also have contributed to the decreased $\mathrm{P}_{\mathrm{CO}_{2}}$. As one would expect, right atrial $\mathrm{pH}$ was lower than arterial $\mathrm{pH}$ because the venous blood contained more carbon dioxide.

It has been documented that severe acidosis and deficient oxygenation of tissues lead to anaerobic glycolysis with increased lactate formation, myocardial depression, and catecholamine release. ${ }^{19,20}$ Acidosis was never present in these patients as a potential cause of these events. The significant progressive increase in lactate concentration throughout operation and its continued high level postoperatively was seen in cardiovascular surgery by others. ${ }^{21}$ This cannot be construed as necessarily indicating that anaerobic glycolysis was occurring, since several factors known to cause increased lactate levels were present: respiratory alkalosis was present throughout the study, and glucose was used as a vehicle for drug administration. ${ }^{22}$ Halothane has been found not to cause excess lactate production in patients. ${ }^{23}$

Significant arteriovenous differences of oxygen, carbon dioxide, and $\mathrm{pH}$ were seen as changes occurred in both the tissues and the lungs. With no known exchange of electrolytes or metabolites taking place in the lungs, venous and arterial concentrations must be the same in the presence of steady amounts in the blood. If arteriovenous differences were found, then an unsteady state existed-that is, addition or loss of that constituent to or from the blood. Another possible cause of the data showing significant arteriovenous differences is relative inaccuracy of the method of measurement.

Metabolism of NEFA is the major energy source of the body ${ }^{24}$ and myocardium 
after fasting. NEFA is the transport form of fat, with an extremely rapid turnover rate, and blood levels of it are sensitive to hormonal control. Other energy-producing metabolites used by the body are glucose, ${ }^{25}$ ketone bodies, ${ }^{24}$ lactate, and pyruvate. Increase in blood sugar can decrease NEFA concentration, ${ }^{25}$ as does an increase in insulin. These patients had a sufficient glucose load, but the concentration of NEFA did not decrease to normal until after the operation, probably due to the continued stimulus of catecholamines released during operation.

Ketone bodies, mainly acetoacetate and $\beta$-hydroxybutyrate, increase during the carbohydrate deprivation of fasting ${ }^{21}$ and rapidly disappear after administration of glucose or insulin. ${ }^{24}$ Ketosis persisted in this series, indicating continued use of fat for energy in spite of the increased blood glucose level, but with insulin levels not above normal. Insulin did not increase above preinduction levels on the day of operation, but did double in concentration on days 2 and 3 . This is consistent with the known effect of insulin release being inhibited by catecholamines. ${ }^{26}$ The changes seen in carbohydrate and fatty acid metabolism agree with those reported by Griffiths. ${ }^{27}$ The mechanisms of action of insulin are well described by Rieser. ${ }^{28}$

Sodium, potassium, and calcium ions are essential to normal cellular function, and their serum levels reflect extracellular concentrations. Osmolality was subnormal at almost all times, indicating slightly reduced solute concentration in the blood. Hyponatraemia, probably due to water retention, was found by Moore ${ }^{29}$ to be most marked on the second and third postoperative days. Most noteworthy in the findings relative to electrolytes and water was that they remained so close to normal.

The duration as well as type of operation had little influence on the variables studied. The study showed that patients undergoing anaesthesia and general surgery utilize fat predominantly for energy, in addition to utilization of glucose.

\section{SUMMARY}

Oxygen, acid-base components, electrolytes, and energy-producing metabolites were measured in arterial and mixed venous blood before, during, and for three days after abdominal operations in 11 patients. A respiratory alkalosis without a metabolic component was present throughout most of the study interval. Predictably, arteriovenous differences were not found for any electrolyte or metabolite. Arterial and venous oxygen tensions were satisfactory throughout anaesthesia, but the postoperative $\mathrm{Pa}_{2}$ indicated considerable persisting atelectasis. Arterial concentrations of non-esterified fatty acids and ketone bodies were increased before anaesthesia and throughout the operation. Blood sugar increased during the operation and remained above normal postoperatively, probably from intravenous solutions. Mean concentrations of immunoreactive insulin remained in the normal range in spite of this increase in blood sugar. Fat metabolism appeared to predominate, and ketosis occurred in the presence of increased blood sugar. Lactate and pyruvate levels increased steadily throughout the operation and decreased postoperatively.

Careful maintenance of arterial oxygen tension and of the circulation during and after anaesthesia for general surgery results in little change in acid-base balance and electrolytes. The changes in blood levels of energy-producing metabo- 
lites are moderate and usually reverse themselves. Duration of operation or type of surgery had little influence on the variables studied.

\section{RÉSUMÉ}

Avant l'opération, durant l'opération, et durant trois jours après des opérations abdominales chez onze malades, nous avons mesuré, dans le sang artériel et dans un mélange de sang veineux l'oxygène, l'équilibre acide-base, les électrolytes et les métabolites énergétiques. Presquà toutes les phases de cette étude, nous avons observé une alcalose respiratoire sans participation métabolique. Tel que préru, nous n'avons pas trouvé de différences artérioveineuses pour aucun des électrolytes ou des métabolites. Les concentrations artérielles d'acides gras non estérifiés et de corps cétogènes étaient augmentées avant l'anesthésie et durant l'opération. Au cours de l'opération, la glycémie a augmenté et, après l'operation, elle est demeurée au-dessus de la normale, probablement à cause des solutés donnés par voie endoveineuse. Les concentrations moyennes d'insuline immunoréactive sont demeurées à un niveau normal en dépit de cette hyperglycémie. Le métabolisme des graisses a semblé prédominer et l'acétone est apparue en présence d'hyperglycémie. Les taux de lactate et de pyruvate ont augmenté de façon régulière au cours de l'opération et ils ont diminué dans les suites opératoires.

Un soigneux maintien de la tension en oxygène du sang artériel et de la circulation au cours et après l'anesthésie pour la chirurgie générale a été suivi de peu de changements sur l'équilibre acide-base et sur les électrolytes. Les changements sur le taux des métabolites énergétiques sanguins sont faibles et, d'habitude, se rétablissent. La durée de l'opération et la sorte de chirurgie n'influencent que très peu les paramètres étudiés.

\section{REFERENCES}

1. Mofritt, E. A.; Rosevear, J. W.; \& McGoon, D. C. Myocardial Metabolism in OpenHeart Surgery: Arterial Levels of Metabolites, Electrolytes, Oxygenation, and Acid-Base Balance. Anesth. \& Analg. 48: 633 (1969).

2. MoffitT, E. A.; Roseveap, J. W.; Townsend, C. H.; \& McGoon, D. C. Myocardial Metabolism in Patients Having Aortic Valve Replacement. Anesthesiology. (In press.)

3. Moffitr, E. A.; Rosevear, J. W.; Molnar, G. D.; \& McGoon, D. C. Myocardial Metabolism in Open-Heart Surgery: Correlation with Insulin Response. (Not yet published.)

4. Robertson, J. T.; Schick, R. W.; Morgan, F.; \& Matson, D. D. Accurate Placement of Ventriculo-atrial Shunt for Hydrocephalus under Electrocardiographic Control. J. Neurosurg. 18: 255 (1961).

5. Garcia, E.; Mrchenfeider, J. D.; \& Theye, R. A. Right Atrial Oxygen Levels during Anaesthesia and Surgery, Canad. Anaesth. Soc. J. 15: 593 (1968).

6. Singen, R. B. \& Hastings, A. B. An Improved Clinical Method for the Estimation of Disturbances of Acid-Base Balance of Human Blood. Medicine (Balt.). 27: 223 (1948).

7. Bierman, E. L.; Dole, V. P.; \& Roberts, T. N. An Abnormality of Nonesterified Fatty Acid Metabolism in Diabetes Mellitus. Diabetes. 6: 475 (1957).

8. Broom, W. L. The Determination of Ketone Bodies in Biologic Fluids. J. Lab. Clin. Med. 51: 824 (1958).

9. WANG, C. C. Improvements in the Methods for Calcium Determination in Biological Material. J. Biol. Chem. 111: 443 ( 1935).

10. Bergmeyer, H. U. Methods of Enzymatic Analysis. Translated by D. H. Williamson with assistance of W. Bartley. New York: Academic Press, Inc. (1963).

11. Morgan, C. R. \& Lazarow, A. Immunoassay of Insulin: Two Antibody System; Plasma Insulin Levels of Normal, Subdiabetic and Diabetic Rats. Diabetes. 12: 115 (1963). 
12. Laver, M. B. \& Serfen, A. Measurement of Blood Oxygen Tension in Anesthesia. Anesthesiology. 26: 73 (1965).

13. Nunn, J. F.; Bergman, N. A.; Coleman, A. J.; \& Jones, D. D. Factors Influencing Arterial Oxygen Tension during Anaesthesia with Artificial Ventilation. Brit. J. Anaesth. 37: 898 (1965).

14. Stephen, C. R. \& Talton, I. Immediate Postoperative Care, with Particular Reference to Blood-Gas Studies. Canad. Anaesth. Soc. J. 11: 586 (1964).

15. Hamilton, W. K.; McDonald, J. S.; Fischen, H. W.; \& Betrards, R. Postoperative Respiratory Complications: A Comparison of Arterial Gas Tensions, Radiographs and Physical Examination. Anesthesiology. 25: 607 (1964).

16. Tarhan, S.; Moffrit, E. A.; \& SEssLER, A. D. The Effect of Dead-Space Rebreathing on Postoperative Atelectasis. Anesth. \& Analg. (In press.)

17. Clowes, G. H. A., JR.; Alichniewicz, A.; Del Guerico, L. R. M.; \& Gilespie, D. The Relationship of Postoperative Acidosis to Pulmonary and Cardiovascular Function. J. Thorac. Cardiov. Surg. 39: 1 (1960).

18. Nunn, J. F. \& Paxne, J. P. Hypoxaemia after General Anaesthesia. Lancet. 2: 631 (1962).

19. Clowes, G. H. A., Jr. Acid-Base Balance during and after Cardiopulmonary Bypass Procedures. Am. J. Cardiol. 12: 671 (1963).

20. Bresslen, R. The Biochemistry of Ketosis of Fasting. Ann. New York Acad. Sc. 104: 735 (1963).

21. Jellinek, M.; Cooper, T.; Willman, V. L.; Kaiser, G. C.; \& Hanlon, C. R. Alterations in Blood Carbohydrates and Lipids during Extracorporeal Circulation in Man. Trans. Am. Soc. Artif. Intern. Organs. 11: 127 (1965).

22. Huckabee, W. E. Relationships of Pyruvate and Lactate during Anàerobic Metabolism: I. Effects of Infusion of Pyruvate or Glucose and of Hyperventilation. J. Clin. Invest. 37: 244 (1958).

23. Lowenstein, E.; Clark, J. D.; \& Villareal, Y. Excess Lactate Production during Halothane Anesthesia in Man. J.A.M.A. 190: 1110 (1964).

24. Foster, D. W. Studies in the Ketosis of Fasting. J. Clin. Invest. 46: 1283 (1967).

25. Dole, V. P. A Relation Between Non-esterified Fatty Acids in Plasma and the Metabolism of Glucose. J. Clin. Invest. 35: 150 (1956).

26. Havel, R. J. The Autonomic Nervous System and Intermediary Carbohydrate and Fat Metabolism. Anesthesiology. 29: 702 (1968).

27. Griffiths, J. A. The Effects of General Anaesthesia and Hexamethonium on the BloodSugar in Non-diabetic and Diabetic Surgical Patients. Quart. J. Med., n.s. 22: 405 (1953).

28. Rieser, P. Insulin, Membranes, and Metabolism. Baltimore: Williams \& Wilkins Company (1967).

29. Moore, F. D. Metabolic Care of the Surgical Patient. Philadelphia: W. B. Saunders (1959), p. 37. 